\title{
J.M.G. Le Clézio: the role of a Nobel laureate in the crossover phenomenon
}

Abstract: With the extraordinary success of J.K. Rowling's Harry Potter books, crossover fiction has often been seen first and foremost as a commercial phenomenon. However, it has long been a literary phenomenon that is only recently receiving the acknowledgment that it deserves from the literary establishment. Child-to-adult crossover books have now become contenders for prestigious mainstream literary awards. A few rare examples even pre-date the crossover craze issued in by Harry Potter. In 1995, Dianne Hofmeyr's Boike, you better believe it was awarded the M-Net Book prize, the most important literary prize in South Africa, beating out J.M.G. Coetzee's Master of Petersburg. Nobel laureate Nadine Gordimer had also been nominated, but withdrew. In 2001, the final volume in Philip Pullman's His dark materials became the first children's book both to win the Whitbread book of the year award and to be longlisted for the Booker prize. The next year, the award was given to Yann Martel's Life of Pi, the first Booker prize winner ever to have true crossover appeal. In 2008, the most prestigious literary prize of all, the Nobel prize for literature, was awarded to the French novelist JMG Le Clézio, a crossover author who has never distinguished between adult fiction and children's fiction. This paper proposes to examine Le Clézio's place within the crossover phenomenon and to show how his winning of the Nobel prize for literature marks a very significant milestone in crossover fiction's path to literary respectability.

J'aimerais bien m'adresser à tout le monde.

J.M.G. Le Clézio

In 2008, the Nobel prize in literature was awarded to Jean-Marie Gustave (J.M.G.) Le Clézio, a French novelist who, for many years, has been widely considered to be the greatest living author writing in French. The Nobel prize confirmed that he is among the greatest 
living authors writing in any language. Le Clézio's work has not received the attention it deserves outside French-speaking countries, although the eyes of the media and the public around the world were focused on the reclusive author after the Nobel win. Journalists and critics commenting on the award have overlooked a fundamental aspect of Le Clézio's writing: the Nobel laureate is a crossover author who has never distinguished between adult literature and children's literature. The French writer figures prominently in my book Crossover fiction: global and historical perspectives, which was published only weeks before the Nobel prize announcement. The awarding of the world's most prestigious literary prize to Le Clézio marks a very significant milestone in crossover fiction's path to literary respectability.

\section{Crossover fiction achieves literary credibility}

With the extraordinary commercial success of J.K. Rowling's Harry Potter saga and other super crossovers, crossover fiction has been seen largely as a marketing and mass media phenomenon. However, it has long been a literary phenomenon that is only recently receiving the acknowledgment that it deserves from the literary establishment. While there are still those who stubbornly refuse to see crossover fiction as "serious literature", crossover books have become contenders for prestigious mainstream literary awards. A few crossover works had actually achieved this status before Harry Potter ushered in the current crossover craze. In 1995, Dianne Hofmeyr's novel Boikie, you better believe it was awarded the M-Net book prize (now the M-Net literary award), the most important literary prize in South Africa, beating out J.M. Coetzee's Master of Petersburg. Nobel laureate Nadine Gordimer had also been nominated for the award, but withdrew. It would seem that the Nobel laureate did not want her work associated with popular novels that were even read by children. For a time following Hofmeyr's win, children's novels were not allowed to compete for the prize.

Since the advent of Harry Potter, crossover novels have received an increasing number of mainstream awards. In 2001, Philip Pullman became the first crossover author in Britain to win a major mainstream literary prize. The third novel of His dark materials achieved what the third Harry Potter had failed, by one vote, to do two years earlier. The amber spyglass overwhelmingly won the 2001 Whitbread book of the year award, the British book world's second highest honour after the Man booker prize, becoming the first children's book winner since 
the award's inception to claim the overall prize. After receiving the Book of the year award, Pullman stated: "I have always believed that children's books belong with the rest, in the general field, and general marketplace and general conversation about books" (Lister 2002). In 2001, The amber spyglass also became the first children's book to be longlisted for the prestigious Booker prize. Mark Haddon's The curious incident of the dog in the night-time (2003), published simultaneously for adults and children, followed a similar, but slightly different path two years later. It won the fiction section of the Whitbread prize as an adult novel before taking the overall Whitbread prize, in addition to be longlisted for the Booker. In the intervening year, 2002, Britain's top literary award went to Yann Martel's Life of Pi, the first Booker prize-winning novel ever to have true crossover appeal. The awarding of the Nobel prize in literature to Le Clézio in 2008 is a clear indication that the literary establishment now recognizes that the world's greatest writers appeal to readers of all ages.

Le Clézio, who has published extensively for young readers as well as adults since the late 1970s, is not the first Nobel laureate with titles for both readerships. He joins the writers Rudyard Kipling, Selma Lagerlöf, Gabriela Mistral, Toni Morrison, and Isaac Bashevis Singer. However, these authors are largely crosswriters rather than crossover authors, that is, they write for child and adult audiences in separate works rather than in works read by both audiences. Fifteen years prior to his Nobel win, at the 1993 International Festival of authors at Harbourfront in Toronto, Le Clézio told me that he makes absolutely no distinction between adult fiction and children's fiction (Beckett 1997, 293). ${ }^{1}$ Like many crossover authors, he refuses to consider children's literature as a genre separate from adult literature or the general field of literature. In fact, although he has published at least a dozen "children's" titles, Le Clézio, persistently claims that there is no such thing as children's literature (Beckett 1997, 296).

For many writers, the greatest works of literature are those that appeal to children as well as adults. Like Le Clézio, Michel Tournier is one of the best-known and most successful contemporary French novelists. His first novels, written and published for adults, won France's two most important literary prizes (the Grand prix du roman de l'académie française and the Prix Goncourt), but very early in his career he rejected the "gibberish" of the rather abstruse sentences of which he had once been so proud and adopted a style "aimed at twelve-year-old children." In 1986, he admitted: "At the outset of my work, I had Thomas Mann for ideal, today it is Kipling and London" (Garcin 1986). Pronouncing the texts of Racine, Shakespeare, 
and Balzac "second-rate" on the basis that they "put off" children and are only good enough for adults, Tournier strives to emulate authors such as Charles Perrault, the Brothers Grimm, Hans Christian Andersen, La Fontaine, Lewis Carroll, Selma Lagerlöf, Rudyard Kipling, and Antoine de Saint Exupéry, whose works read by both children and adults are, in his view, the "highest summits of world literature" (Tournier 1982, 34). The titles and authors admired by Le Clézio also fall into the crossover category: The Arabian nights, Robert Louis Stevenson, Jack London, Charles Dickens, and Mark Twain. Recalling the books he read as a child, books such as London's The call of the wild, Le Clézio points out that they weren't "children's literature" even though they were "largely read by children." The author claims to have read "the major part of adult literature when [he] was about ten years old, from Robinson Crusoe to Stevenson," having borrowed the books from his grandfather's library (Beckett 1997, 298, 290). Le Clézio's writing, like Tournier's, has evolved in the direction of crossover literature, adopting a simpler, more elemental narrative that is accessible to younger readers while appealing to adults. Since the outset of his career in the 1960s, however, Le Clézio had been expressing his discontentment with the literary novel.

\section{From adult fiction to children's book}

Le Clézio became a literary sensation in 1963, when, at the age of twenty-three, his first novel Le procès-verbal (The interrogation), won the prestigious Prix Renaudot and also figured on the short list for the Prix Goncourt, causing quite a stir in French literary circles. Hailed on the dustjacket of La guerre as "one of the most exciting young writers since Camus," Le Clézio has consistently maintained his status as a major novelist. In 1980, he became the first winner of the Grand prix Paul Morand, awarded by the Académie française. Although the formal experimentation that marked his early works was seen in the light of the nouveau roman, contrary to most of his contemporaries, Le Clézio was not interested in form for its own sake. Critics were not long in agreeing that Le Clézio was disconcertingly unclassifiable. In his early novel Le livre des fuites, published in 1969, the narrator-author attempts to write a novel that would be "a real adventure story" (Le Clézio 1969, 186). Le Clézio admits that as a child, he couldn't imagine a novel "other than an adventure novel" (Beckett 1997, 291), and the childhood dream of "writing an adventure story" in the manner of Verne, Stevenson, London, and Melville never ceased to haunt the author (Lhoste 1971, 15). The narrator 
who aspires to write an adventure novel pens the following diatribe against novels in general:

Novels without adventures ... Psychological novels, romantic novels, cloak-and-dagger novels, realistic novels, saga novels, satirical novels, detective novels, science-fiction novels, new novels, verse novels, essay-novels, novel-novels! . . Never novels about the hereafter, never novels for rebirth, or for survival! (Lhoste 1971, 60).

He speaks derisively of novelists - Stendhal, Dostoyevsky, Joyce, Gide, Proust - and calls them all "liars" (58) because the novel remains detached from the world and fails to express reality, truth, the absolute.

Le Clézio's condemnation of the literary novel in the 1960s is remarkably similar to the current criticism which seems to have been a catalyst for the crossover phenomenon. The awarding of major mainstream literary prizes to crossover novels in recent years is a sign of the general deception with a great deal of hyped literary fiction. Adult fiction has been coming under increasing criticism for its abstruseness, the "gibberish" that Tournier condemns in his own early adult novels. Some of this criticism has been voiced by successful crossover authors like Mark Haddon and Philip Pullman.The year before The amber spyglass was longlisted for the Booker prize, numerous critics expressed their disenchantment with the 2000 prize winner, Margaret Atwood's The blind assassin. Caught up in form, the literary novel, according to many, has become detached from the world and its truths. The British novelist Jonathan Myerson claims categorically that a children's novel cannot provide "truths about human life" or "psychological understanding." In bafflement, he wonders why avid adult readers "sandwich" children's books between "McEwan and Balzac, Roth and Dickens," but the author answers his own question by proudly holding up his own "difficult, unreadable . . . novels" (Myerson 2001). The self-conscious literariness of much adult literary fiction often makes for very dull reading. Commenting, in 2003, on the increasingly "abstruse and remote" nature of literary fiction, the children's author S. F. Said wrote: "As modernism moved into postmodernism, high literature became so bogged down in theory that it became dull at best, meaningless at worst." This is contrasted with children's literature of the same period, which offered "vivid, bold storytelling of a profundity and scope that dwarfed any Booker prize winner's" (Said 2003). Contrary to Myerson, many authors 
believe that only crossover literature can offer those truths. Philip Pullman explains why he writes for children: "Children's books still deal with the huge themes which have always been part of literature - love, loyalty, the place of religion and science in life, what it really means to be human. Contemporary adult fiction is too small and too sterile for what I'm trying to do" (Eccleshare 1996, 15).

The key to the current crossover phenomenon seems to lie largely in the art of storytelling. The success of crossover titles is attributed over and over to the power of the story. Writers and publishers of so-called literary fiction are accused of having long neglected the story. Pullman has repeatedly attacked Britain's adult novelists for their neglect of narrative. In 1999, he claimed that "there are very few writers of what one might call the literary Booker prize short-list novel who are good at stories and who think stories are important" (Parsons and Nicholson 1999, 122). Adults, as well as children, desire and need stories. Francis Spufford, the author of the 2002 bestselling memoir The child that books built, believes that children's books fill a need for compelling stories currently missing in adult fiction. Humans are, as one commentator put it, "story-telling, story-listening apes" (Taylor 2002). Le Clézio's entire corpus is an apology of story. Bea B.'s quest in La guerre is that of the author himself; she senses clearly that the key to survival is to be found in story (Le Clézio 1970, 191). Among the examples she gives of the kind of stories she would like to tell, at least one would seem to be a children's story: "Story of the silly cat" (ibid, 196). Le Clézio's first novel, Le procès-verbal, begins: "Once upon a little time, ..." (Le Clézio 1963, 1). The story of "Black Oradi," five chapters of Oradi's "advenchers," written in childish handwriting in a little yellowing exercise book by the eightyear-old budding author, is embedded in Le déluge in 1966 complete with spelling mistakes. Le Clézio, who has always been first and foremost a storyteller, returns repeatedly to the power of story in his novels, often embedding examples of simple stories that could be children's stories.

Unlike the novelists for adults criticized by Philip Pullman and others, Le Clézio is a true storyteller. In his desire to tell a simple, yet profound story, Le Clézio adopted, toward the end of the 1970s, a more traditional narrative form reminiscent of the adventure story that the narrator of Le livre des fuites despaired of writing. With Mondo et autres histories, published in 1978, Le Clézio's works become accessible to a much wider public which often includes young readers. In L'inconnu sur la terre, a poetic essay published shortly before Mondo, the author describes the language to which he aspires: "My language 
would no longer be only that of men and their books, but would address anyone on earth, and anyone would be able to understand it" $(1978,314)$. Henceforth, his language would be simpler, more primal, and more elemental. Not surprisingly, it was at this turning point in his career that Le Clézio's first book was published for children. Voyage au pays des arbres, which appeared in 1978, is the only book that has been written exclusively for children. Paradoxically, Voyage au pays des arbres is the only one of his children's books, according to the author, that has not been well received by young readers. It seems that children prefer his crossover texts.

\section{Adult-to-child crossovers}

With the exception of Voyage au pays des arbres, all of Le Clézio's so-called children's books were originally published for adults before being issued, with only paratextual changes,

J.M.G. Le Clézio's Voyage au pays des arbres. Ill. Henri Galeron. Gallimard, 1990.

The illustration is not available in this edition.

in children's editions. They fall into the category of what I term adult-to-child crossovers. The initiative for many such books comes from publishers anxious to capitalize on their stable of bestselling adult authors. The phenomenon is particularly common in France, where publishers often repackage for children works by authors of adult fiction or écrivains. In French, the term écrivain is reserved for authors who write solely or primarily for adults, as opposed to "les auteurs jeunesse," a distinction that has been questioned insistently by a number of children's authors (see Madore 2001). In a book published in France in 2000, Dominique Noguez coined the term "grantécrivain," which could be translated as "greatwriter." She describes the grantécrivain, a species she feels is particularly French, as a writer whose greatness is recognized and "mythifie" (mythologized) during his or her lifetime and who plays a major role not only in the literary world, but also on the cultural scene and in public life in general (Noguez 2000,13). Le Clézio is one of 
a number of French writers or écrivains who, according to Noguez's definition, would be classifed as grantécrivains. The important French publishing house Gallimard, who issues Le Clézio's fiction, has consistently brought out their most eminent authors of adult fiction in editions for children. In the years following the creation of their children's division in 1972, they repackaged short fiction by many of their most renowned authors, including Marcel Aymé, Jean Giono, Michel Tournier, Marguerite Yourcenar, and, of course, Le Clézio. In Le Clézio's case, the editorial decision to repackage adult texts for children was perhaps not so much a commercial endeavour as a sincere attempt to bring together major adult authors and young readers. Pierre Marchand, the founder of Gallimard's children's division, seems to have truly felt that Le Clézio wrote more for young people than for adults when he suggested that some of his adult works be published for children. This editorial policy, which clearly demonstrates that literature transcends the boundaries between the different categories of readers, contrasts starkly with the general tendency to separate children's literature from general literature and to subdivide children's literature into ever more precise categories.

Almost all the titles in Le Clézio's corpus for young readers are taken from two short story collections published in the years immediately following his adoption of a new manner. Le Clezio admits that he became a "children's author" when Marchand suggested that certain stories from Mondo be published in a paperback edition for young readers. The proposal appealed to Le Clézio, whose goal had always been to address everyone. Four short stories from Mondo were eventually issued separately in children's editions. The conciseness of the short story obviously lends itself well to a transposition from adult fiction to children's book.

The first story chosen to crossover in 1980 was Lullaby, which is the story of a young girl's initiation. The fact that Le Clézio's works are generally initiatory stories explains much of their appeal with young readers. With the exception of Lullaby, which is longer than the others, Gallimard has published Le Clézio's short stories in pairs in the Folio Junior series. In 1982, "Celui qui n'avait jamais vu la mer" and "La montagne du dieu vivant" appeared together in a volume that bears only the title of the first story. Daniel, the young protagonist of the first story runs away to the sea with his treasured book about the voyages of Sinbad. "La montagne du dieu vivant" is also an initiatory tale that deals with a boy's coming of age, in this case a young Icelandic boy, Jon, who encounters a luminous, smiling child, not unlike certain images of Buddha, on the summit of Reydarbarmur 
Mountain. Jon's spiritual adventure provides an excellent example of the encounter with the "other side" of reality that Le Clézio wishes to offer all his readers, both young and old. Le Clézio obviously felt that other stories from Mondo had crossover potential because, in a letter to the well-known French illustrator Georges Lemoine in 1990, Le Clézio suggested the possibility of illustrating "Hazaran" or "La roue d'eau" (The water wheel) for the Folio Junior series. Several short stories were also excerpted from a second adult collection, $\mathrm{La}$ ronde et autres faits divers, published in 1982. In 1985, the stories "Villa Aurore" and "Orlamonde" were published together in the Folio Junior paperback series. In 1990, "Peuple du ciel” (Sky people), a beautiful tale from Mondo about a blind Hopi girl, and "La grande vie" (The good life), an initiatory story from La ronde... about twin French girls who run away, were packaged together in the same series.

A number of critics have pointed recently to the "new" trend of repackaging adult texts in picturebook format. Although this type of transposition has become more widespread in recent years, it is not a new phenomenon in France. Since the creation of its children's division, Gallimard has transformed many adult texts into "picturebooks". ${ }^{2}$ Often the illustrator Georges Lemoine is entrusted with the graphic interpretation of these texts. The French illustrator admits that he is very interested in illustrating contemporary literature "when it is of the quality of Le Clézio, Yourcenar, Tournier, Bosco..." (Lemoine 2003), that is, adult authors who appeal to audiences of all ages. Although it was often Pierre Marchand who proposed certain texts to Lemoine, it was the illustrator who approached Marchand about illustrating Le Clézio's texts. A year after its publication in the Folio Junior series with "La grande vie," "Peuple du ciel" appeared in picturebook format with illustrations by Lemoine. While Le Clézio dedicated the book to my son in 1993, he expressed his admiration for Lemoine's superb illustrations. Lemoine kindly shared with me the letters that Le Clézio sent to him during the genesis of the illustrated book in 1988 and 1990. The correspondence between Le Clézio and Lemoine shows the great interest the author took in the tale's crossover to a young audience.

Published as a "picturebook" in 1985, Balaabilou represents another strategy used by publishers to address adult texts to young readers, namely that of excerpting a passage from an adult novel and giving it a new paratext designed to appeal to children. In 1980, Gallimard had extracted the chapter "Barbedor" from Michel Tournier's adult novel Gaspard, Melchior et Balthazar (1980) and published it separately with illustrations by Georges Lemoine, in their children's series En- 
fantimages. The successful strategy was adopted for Le Clézio's novel Désert, also published in 1980. According to Le Clézio, it was Gallimard who suggested that a passage be taken out of Désert, winner of the Grand Prix Paul Morand, and turned into a children's book in 1985. Although the copyright page indicates that Balaabilou is a "nouvelle" (short story) extracted from Désert, like Tournier's Barbedor it is actually an oriental tale - crossover genre par excellence - in the tradition of the Arabian Nights. The tale of "Balaabilou," embedded in the novel by the anonymous narrator, is told by the old fisherman Naman as he caulks his boat on the beach, to the young heroine Lalla and the other village children who listen spellbound around the fire. The original hardcover "picturebook" edition of Balaabilou appeared hors série with no designated readership; the more recent Folio Cadet edition specifies a readership, but leaves it open-ended: from nine years of age.

In addition to the chapter excerpted from an adult novel, an adult novella by Le Clézio was also repackaged for children in its entirety. Pawana, a work originally written for the stage and published for adults in 1992, was reissued for children in 1995, again with illustrations by Lemoine. The book appeared in Gallimard's Lecture Junior series for children nine years old and up. Interestingly, the story has been more successful in the children's edition than in the adult edition. We are reminded of the appropriation by young readers of novels such as Robinson Crusoe and Treasure Island, which Le Clézio himself devoured as a child. The novella reflects the aspiration that Le Clézio has harboured since childhood, that of writing an adventure story in the manner of Stevenson or Melville.

Sirandanes, a collection of traditional riddle-poems from Mauritius published for an adult audience by Le Clézio and his wife Jemia in 1990, was issued in a children's edition by Seghers Jeunesse in 2005, with virtually no changes even to the paratext. It did, however, include a new afterword by Danielle Henky, which, according to the publisher, was intended to make the riddles accessible to the largest possible number of readers. It is quite probable, however, that young readers appreciate the collection as much, if not more, than adults, since riddles are an important part of children's culture. The new edition was entirely superfluous. In both editions, the riddles appear in Creole along with a French translation, and are followed by a short Creole lexicon, while the illustrations, by Le Clézio himself, are very simple watercolours. From the outset, Sirandanes was a crossover book suitable for readers of all ages. 
Unlike many adult authors, Le Clézio does not deny writing for children in order to avoid the "children's author" label and to preserve his literary reputation, but rather because he firmly believes that, with the exception of literature "for tiny tots," there is no such thing as children's literature, but only "literature" (Beckett 1997, 293). After the release of the English translation of his adult novel Le chercheur d'or (1985), The Prospector, in 1993, Le Clézio told me that it could no doubt be read by a juvenile audience, reiterating that he makes no distinction between adult and children's literature. However, Le Clézio is especially interested in addressing readers aged ten to twelve years. He gives the child reader a privileged status that surpasses that of the adult reader, believing that pre-adolescent children, in the process of discovering literature, read with a "freshness" and "conviction" that they will never again experience (Beckett 1997, 293). The year Le Clézio began publishing for children, the narrator of L'inconnu sur la terre expresses the author's goal: "I want to write to be on the side ... of children, on the side of those who see the world as it is, who know all its beauty" (312). The author states that writers must never lose sight of the fact that they are always also addressing "children on the threshold of adolescence," whom he considers to be the only "true readers" (Beckett 1997, 299). He would undoubtedly agree with Tournier, who claims that a book, in particular a novel, is worth very little "if its author cannot communicate its substance to an audience of ten-year-olds" (Tournier 1971,7). At the same time, Le Clézio insists that pre-adolescent readers should be addressed in the same manner as adults. His desire to write for all ages is clear from a very early stage in his career. In a 1969 interview, only six years after the publication of his first prize-winning novel for adults, Le Clézio made the statement that serves as an epigraph to this article and that expresses the aspiration of the true crossover author: "I would like to address everyone" (Lhoste 1969, 30).

Biographical information: Sandra L. Beckett is a professor at The department of modern languages, literatures and cultures, Brock University St. Catharines, Ontario Canada.

Contact: sbeckett@brocku.ca 


\section{Bibliography}

Beckett, Sandra L. De grands romanciers écrivent pour les enfants. Montréal: Les presses de l'Université de Montréal; Grenoble: Éditions littéraires et linguistiques de l'Université de Grenoble, 1997.

Beckett, Sandra L. Crossover fiction: global and historical perspectives. New York and London: Routledge, 2009.

Eccleshare, Julia. "Northern lights and christmas miracles." Books for keeps 100 (September 1996): 15.

Garcin, Jérôme. “Interview avec Michel Tournier." L'Événement du jeudi, January 9-15, 1986.

Haddon, Mark. The curious incident of the dog in the night-time. London: Jonathan Cape, 2003.

Hofmeyr, Dianne. Boikie, you better believe it. Cape Town, SA: Tafelberg, 1994.

Le Clézio, J.M.G. Balaabilou. Paris: Gallimard, 1985.

Le Clézio, J.M.G. Celui qui n'avait jamais vu la mer. Folio Junior. Paris: Gallimard, 1988.

Le Clézio, J.M.G. Désert. Paris: Gallimard, 1980.

Le Clézio, J.M.G. La grande vie [followed by] Peuple du ciel. Folio Junior. Paris: Gallimard, 1990.

Le Clézio, J.M.G. La guerre. Paris: Gallimard, 1970.

Le Clézio, J.M.G. La ronde et autres faits divers. Paris: Gallimard, 1982.

Le Clézio, J.M.G. Le chercheur d'or. Paris: Gallimard, 1985.

Le Clézio, J.M.G. Le procès-verbal. Paris: Gallimard, 1963.

Le Clézio, J.M.G. Le déluge. Paris: Gallimard, 1966.

Le Clézio, J.M.G. L'Inconnu sur la terre. Paris: Gallimard, 1978.

Le Clézio, J.M.G. Le livre des fuites. Paris: Gallimard, 1969. Translated by Simon Watson Taylor under the title The book of flights. London: Cape, 1971.

Le Clézio, J.M.G. Lullaby. Folio Junior. Paris: Gallimard, 1980.

Le Clézio, J.M.G. Mondo et autres histoires. Paris: Gallimard, 1978.

Le Clézio, J.M.G. Pawana. Paris: Gallimard, 1992.

Le Clézio, J.M.G. Pawana. Illus. Georges Lemoine. Lecture Junior. Paris: Gallimard, 1995.

Le Clézio, J.M.G. Peuple du ciel. Paris: Gallimard, 1991.

Le Clézio, J.M.G. Sirandanes. Paris: Seghers, 1990.

Le Clézio, J.M.G. Sirandanes. Paris: Seghers Jeunesse, 2005.

Le Clézio, J.M.G. Villa Aurore [followed by] Orlamonde. Folio Junior. Paris:

Gallimard, 1990. 
Le Clézio, J.M.G. Voyage au pays des arbres. Folio Cadet Rouge. Paris: Gallimard, 1990.

Lemoine, Georges. Letter to Sandra L. Beckett, January 21, 2003.

Lhoste, Pierre. Conversations avec J.M.G. Le Clézio. Paris: Mercure de France, 1971.

Lister, David. "Pullman wins Whitbread for children's fantasy." The independent (London), January 23, 2002.

Madore, Édith, “Les écrivains... et les 'auteurs jeunesse.'” Tangence 67 (Autumn 2001): 23-33.

Martel, Yann. Life of Pi. Toronto: Knopf Canada, 2001.

Myerson, Jonathan. "Harry Potter and the sad grown-ups." The independent, November 14, 2001.

Noguez, Dominique. Le grantécrivain et autres textes. Paris: Gallimard, 2000 .

Parsons, Wendy, and Catriona Nicholson. "Talking to Philip Pullman: an interview." The lion and the unicorn 23.1 (1999): 116-134.

Pullman, Philip. The amber spyglass. London: Scholastic, 2000.

Said, S. F. "The grown-up world of kidult books." The daily telegraph, January 11, 2003.

Spufford, Francis. The child that books built. London: Faber \& Faber, 2002.

Taylor, Debbie. "The Potter effect." Mslexia 14 (Summer/ Autumn 2002).

Tournier, Michel. “Quand Michel Tournier récrit ses livres pour les enfants." Le Monde, December 24, 1971, 7.

Tournier, Michel. "Writing for children is no child's play." UNESCO courier (June 1982); 33-34.

Tournier, Michel. Gaspard, Melchior et Balthazar. Paris: Gallimard, 1980.

Translated by Ralph Manheim under the title The four wise men. New York: Doubleday, 1982.

Tournier, Michel. Barbedor. Enfantimages. Paris: Gallimard, 1980.

Keywords: Le Clézio; crossover; Nobel laureate; story; French novel

1 All translations are mine unless otherwise indicated.

2 As the illustrations are added to existing texts, they are not, strictly speaking, picturebooks, but they have a picturebook format. 